\title{
ANALISIS KUALITAS AIR DANAU KANDUNG SULI KECAMATAN JONGKONG KABUPATEN KAPUAS HULU
}

Lailial Muthifah $^{1}$ Nurhayati $^{2}$ Kiki Prio Utomo ${ }^{1}$

${ }^{1}$ Program Studi Teknik Lingkungan Jurusan Teknik Sipil Fakultas Teknik Universitas Tanjungpura, Pontianak 2Program Studi Teknik Sipil Jurusan Teknik Sipil Fakultas Teknik Universitas Tanjungpura, Pontianak Email: $\underline{\text { muthifahlailial@gmail.com }}$

\begin{abstract}
ABSTRAK
Danau Kandung Suli merupakan sumber air utama bagi penduduk yang dimanfaatkan langsung untuk keperluan domestik seperti mandi dan mencuci, juga untuk budidaya ikan menggunakan keramba. Kegiatan domestik dan budidaya ikan di perairan Danau Kandung Suli akan mengakibatkan penurunan kualitas air. Kualitas air Danau Kandung Suli dalam penelitian ini diuji dengan metode Indeks Pencemaran (IP) dan disesuaikan dengan baku mutu PP No. 82/2001. Tahapan penelitian meliputi pengukuran kedalaman air, pengambilan sampel air, uji kualitas air dan analisis indeks pencemaran air. Sampel air yang dianalisis adalah sampel komposit yang diambil dari bagian dasar perairan dan permukaan perairan. Pengambilan sampel air dilakukan pada inlet sungai, lokasi pemukiman, sekitar keramba, serta kondisi alami air danau. Analisis kualitas air dilakukan secara in situ untuk parameter $\mathrm{pH}$, suhu, kecerahan, TDS, DO, sedangkan analisis laboratorium dilakukan untuk parameter BOD, COD, TSS, fosfat, dan nitrat. Hasil penelitian menunjukkan parameter suhu pada ke 5 titik pengamatan berkisar antara $28^{\circ} \mathrm{C}-31^{\circ} \mathrm{C}$, kecerahan 0,66 m-0,86 m, pH 5,9-6,9, DO 2,92 mg/L-5,42mg/L, BOD 2,28 mg/L-3,9 mg/L, COD 24,26 mg/L$25,20 \mathrm{mg} / \mathrm{L}$, TSS $30,18 \mathrm{mg} / \mathrm{L}-50,10 \mathrm{mg} / \mathrm{L}$, TDS $594,8 \mathrm{mg} / \mathrm{L}-950 \mathrm{mg} / \mathrm{L}$, Fosfat 0,1 mg/L- 0,28 mg/L, dan Nitrat 5,97 mg/L-9,8 mg/L.
\end{abstract}

Kata Kunci: Danau Kandung Suli, Kualitas Air.

\section{ABSTRACT}

Kandung Suli lake is the main source of water for people who are used directly for domestic purposes such as bathing and washing, also for fish farming using keramba. Domestic activities and fish farming in the waters of Lake Kandung Suli will lead to a decrease in water quality. Water quality of Kandung Suli lake in this research was tested by quality standard of PP No. 82/2001. Research steps include measurement of water depth, water sampling, water quality test and water pollution index analysis. Water samples analyzed were composite samples taken from the bottom of the waters and surface waters. Water sampling is done on river inlet, settlement location, around keramba, and natural condition of lake water. Water quality analyzes were conducted in situ for $\mathrm{pH}$, temperature, brightness, TDS, DO parameters, while laboratory analysis was performed for $B O D, C O D, T S S$, phosphate and nitrate parameters. The results showed that temperature parameters at 5 observation points ranged from $28{ }^{\circ} \mathrm{C}-31{ }^{\circ} \mathrm{C}$, brightness $0.66 \mathrm{~m}-0.86 \mathrm{~m}, \mathrm{pH}$ 5.96.9, DO $2.92 \mathrm{mg} / \mathrm{L}-5,42 \mathrm{mg} / \mathrm{L}$, COD 24,26 mg / L-25,20 mg / L, TSS 30,18 mg / L-50,10 mg / L, TDS $594.8 \mathrm{mg} / \mathrm{L}-950 \mathrm{mg} / \mathrm{L}$, phosphate $0.1 \mathrm{mg} / \mathrm{L}-0.28 \mathrm{mg} / \mathrm{L}$, and Nitrate $5.97 \mathrm{mg} / \mathrm{L}-9.8 \mathrm{mg} /$ L.

Keywords: Kandung Suli Lake, Water Quality.

\section{PENDAHULUAN}

Air merupakan salah satu sumber daya alam yang mempunyai peranan penting bagi kehidupan manusia dan makhluk lainnya. Sumber daya air tawar terbagi menjadi dua golongan, yaitu air tanah dan air permukaan. Salah satu jenis air yang tergolong dalam air permukaan adalah air danau. Danau merupakan perairan yang tergenang berbentuk cekungan berisi air yang dikelilingi oleh daratan baik terbentuk secara alami maupun buatan. 
Danau Kandung Suli merupakan sumber air utama yang digunakan masyarakat setempat untuk keperluan sehari-hari terutama mandi dan mencuci. Penduduk Danau Kandung suli sebagian besar menggantungkan hidupnya dari nelayan dan membudidayakan beberapa jenis ikan yang bernilai ekonomis tinggi dengan teknik keramba di lingkungan Danau Kandung Suli. Adanya aktivitas pembudidayaan ikan dalam keramba secara terus menerus di perairan Danau Kandung Suli dapat meningkatkan konsentrasi bahan organik yang akan mempengaruhi beberapa parameter seperti $\mathrm{pH}, \mathrm{DO}, \mathrm{BOD}, \mathrm{COD}$, TDS, fosfat dan nitrat. Kegiatan budidaya ikan dalam keramba selain berpengaruh terhadap beberapa parameter diatas, berpengaruh juga terhadap parameter kecerahan dan TSS. Oleh karena itu, sangat penting dilakukan analisis kualitas air mengingat aktivitas yang dilakukan masyarakat setempat dapat berpengaruh terhadap kualitas air.

\section{METODOLOGI PENELITIAN}

Penelitiaan ini dilakukan pada tanggal 30 juli 2017 di Danau Kandung Suli Kecamatan Jongkong Kabupaten Kapuas Hulu.

Alat digunakan dalam penelitian ini adalah termometer, GPS (Global Positioning System), pH meter, DO meter, TDS meter, pipet tetes, gelas ukur, sarung tangan, masker, Secchi disk, water sampler, kertas label, coolbox, alat tulis, dan kamera. Sedangkan bahan yang digunakan adalah Bahan-bahan yang digunakan dalam penelitian ini adalah sampel air Danau Kandung Suli, es batu, akuades, dan larutan $\mathrm{H}_{2} \mathrm{SO}_{4}$.

Pengambilan sampel air dilakukan secara grab sampel yaitu metode pengambilan sampel secara langsung di badan air yang diteliti dan disesuaikan dengan SNI 6989.57:2008, tentang Metode Pengambilan Sampel Air Permukaan. Titik pengambilan sampel yaitu :

Titik 1 : Penentuan pengambilan sampel dititik 1 ini dengan pertimbangan sebagai perbandingan antara kualitas air danau dengan air sungai. Hasil pengukuran kedalaman pada titik 1 sebesar 7,31 m. Sampel air diambil dikedalaman 0,5 m dari permukaan dan $0,5 \mathrm{~m}$ dari dasar.

Titik 2: Penentuan pengambilan sampel dititik 2 dikarenakan sekitar lokasi ini terdapat lahan perkebunan karet dengan pertimbangan pemanfaatan kawasan hutan sebagai aktivitas perkebunan dapat meningkatkan parameter kualitas air. Hasil pengukuran kedalaman pada titik 2 sebesar $8,26 \mathrm{~m}$. Sampel air diambil dikedalaman 0,5 $\mathrm{m}$ dari permukaan dan 0,5 $\mathrm{m}$ dari dasar.

Titik 3 : Penentuan pengambilan sampel dititik 3 ini dengan pertimbangan sebagai perbandingan antara kualitas air danau dengan air sungai. Hasil pengukuran kedalaman pada titik 3 sebesar 7,45 m. Sampel air diambil di kedalaman 0,5 m dari permukaan dan $0,5 \mathrm{~m}$ dari dasar.

Titik 4 : Penentuan pengambilan sampel dititik 4 dikarenakan sekitar lokasi ini terdapat aktivitas keramba dan pemukiman penduduk yang perairannya dimanfaatkan masyarakat secara langsung. Hasil pengukuran kedalaman pada titik 4 sebesar 7 $\mathrm{m}$. Sampel air diambil dikedalaman 0,5 $\mathrm{m}$ dari permukaan dan 0,5 $\mathrm{m}$ dari dasar.

Titik 5 : Penentuan pengambilan sampel dititik 5 ini dengan pertimbangan sebagai lokasi objek kontrol air danau yang belum dan masih sedikit sumber pencemar. Hasil pengukuran kedalaman pada titik 5 sebesar 8,64 m. Sampel air diambil dikedalaman $0,5 \mathrm{~m}$ dari permukaan dan $0,5 \mathrm{~m}$ dari dasar. 
Pengukuran parameter kualiatas air dilakukan dengan 2 cara, yaitu in situ untuk suhu, kecerahan, pH, DO, TDS dan ex situ untuk BOD, COD, TSS, fosfat, nitrat. Pengujian sampel dilakukan di Laboratorium Pertanian Universitas Tanjungpura.

Data yang diperoleh dibandingkan dengan Peraturan Pemerintah No. 82 Tahun 2001 tentang Pengelolaan Kualitas Air.

\section{Hasil dan Pembahasan}

Danau Kandung Suli merupakan jenis danau tapal kuda yang terbentuk karena adanya aliran sungai kapuas yang berkelok-kelok dan terjadi akibat adanya erosi dan sedimentasi disekitar sungai. Pengambilan sampel air dilakukan pada saat ketinggian permukaan air lebih surut, yaitu pada bulan kering. Panjang danau pada studi kasus adalah $\pm 1,8 \mathrm{~km}$ dari permukaan yang merupakan kawasan pemukiman penduduk, keramba ikan, dan perkebunan karet. Pemukiman masyarakat terletak ditepi Danau Kandung Suli. sementara aktivitas budidaya ikan dengan sistem keramba dilakukan di tepian danau tepatnya di depan pemukiman penduduk. Sebagian besar masyarakat di Danau Kandung Suli saat ini telah memiliki wc disetiap rumah. Akan tetapi, masyarakat di Danau Kandung Suli sebagian besar masih melakukan aktivitas seperti mandi dan mencuci langsung di perairan danau. Limbah yang dihasilkan dari kegiatan masyarakat dibuang secara langsung ke lingkungan tanpa dilakukan pengolahan. Kegiatan utama masyarakat di Danau Kandung Suli untuk memenuhi perekonomiannya adalah budidaya ikan dengan sistem keramba. Keramba yang terdapat di Danau Kandung Suli berjumlah \pm 50 unit dengan jumlah ikan pada setiap keramba \pm 500-800 ekor. Jenis ikan yang dibudidaya dalam keramba adalah ikan toman dan ikan patin. Jenis pakan yang diberikan oleh masyarakat dalam budidaya ikan toman dan patin adalah pelet ikan tipe FF-999 dan ikan kecil hasil tangkapan.

\section{Suhu}

Pengukuran suhu dilakukan secara in situ pada perairan Danau Kandung Suli. Hasil pengukuran suhu disajikan pada Gambar 1.

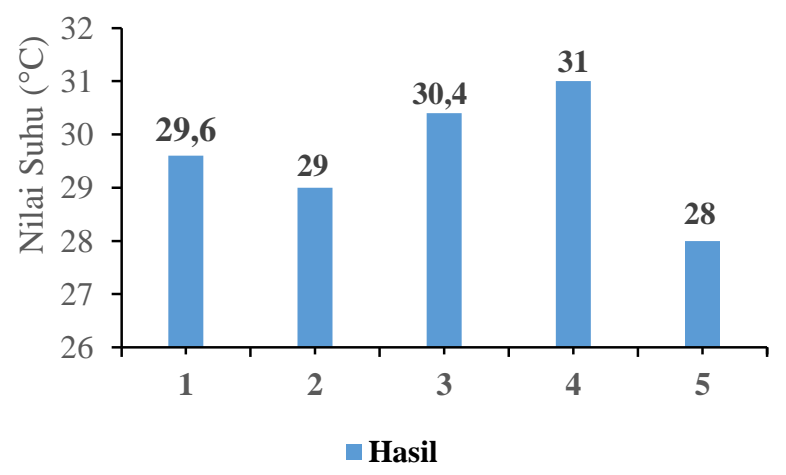

Gambar 1 Hasil Pengukuran Nilai Suhu di Lima Titik Sampel Danau Kandung Suli.

Hasil pengukuran sampel air yang telah dikompositkan bagian permukaan dan dasar pada Danau Kandung Suli menunjukkan bahwa suhu air di perairan Danau dari titik 1 sampai titik 5 berkisar antara $28-31^{\circ} \mathrm{C}$. Nilai suhu pada Titik 4 lebih tinggi dibandingkan titik yang lain, ini dikarenakan pada titik 4 terdapat aktivitas pemukiman dan budidaya ikan. Menurut 
Pujiastuti dkk, (2013) dan Syamiazi dkk (2015), perairan yang baik untuk budidaya ikan dan kehidupan organisme lainnya pada kisaran suhu $25-32{ }^{\circ} \mathrm{C}$.

\section{$>$ Kecerahan}

Pengukuran nilai kecerahan yang dilakukan di Danau Kandung Suli disajikan pada Gambar 2.

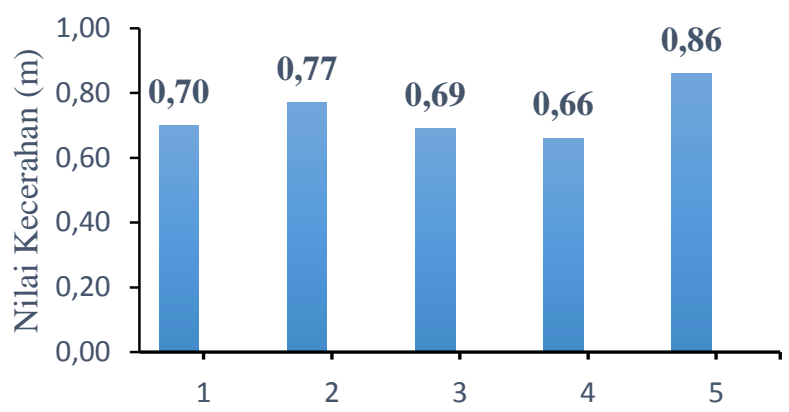

Gambar 2 Hasil Pengukuran Kecerahan di Lima Titik Sampel Danau Kandung Suli.

Hasil pengukuran di Danau Kandung Suli diperoleh nilai kecerahan antara 0,66-0,86 m. Titik 4 nilai kecerahan lebih rendah dibandingkan titik 1,2,3 dan 5. Hal ini dikarenakan lokasi titik 4 merupakan tempat usaha budidaya ikan dengan sistem keramba. Dari hasil pengamatan, ditemukan sisa pakan ikan yang tidak termakan oleh ikan di perairan, sehingga mempengaruhi kecerahan menjadi rendah. Sedangkan menurut Tatangindatu dkk (2013) tingkat kecerahan yang baik untuk perairan danau sebesar $2 \mathrm{~m}$.

$\mathrm{pH}$

Hasil pengukuran pH di Danau Kandung Suli disajikan pada Gambar 3.

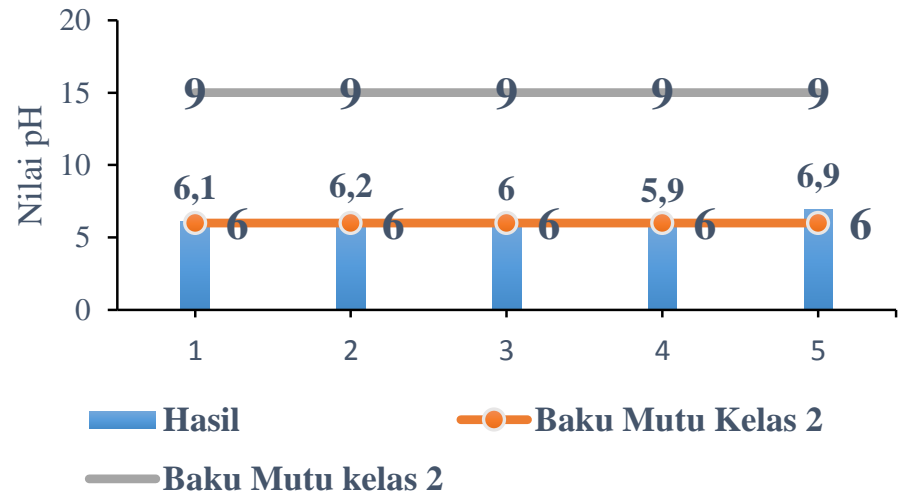

Gambar 3 Hasil Pengukuran Nilai pH di Lima Titik Sampel Danau Kandung Suli.

Berdasarkan baku mutu air Peraturan Pemerintah No. 82 Tahun 2001 tentang Pengelolaan Kualitas Air dan Pengendalian Pencemaran Air, nilai pH terendah ada pada titik 4 yaitu 5,9 dan tertinggi pada titik 5 yaitu 6,9 . Nilai pH pada titik 4 cenderung lebih rendah dibandingkan dengan titik 1, 2, 3 dan 5. Penurunan nilai pH pada titik 4 dipengaruhi oleh aktivitas domestik seperti mandi, cuci dan budidaya ikan secara langsung di perairan. Sesuai dengan pernyataan Tobing dkk (2014), Rizki dkk (2015) dan Yuningsih dkk (2014) yang 
menyatakan bahwa masuknya senyawa organik dan anorganik pada perairan yang bersumber dari aktivitas domestik dan budidaya ikan dapat mempengaruhi nilai $\mathrm{pH}$.

DO

Hasil nilai DO di Danau Kandung Suli disajikan pada Gambar 4.

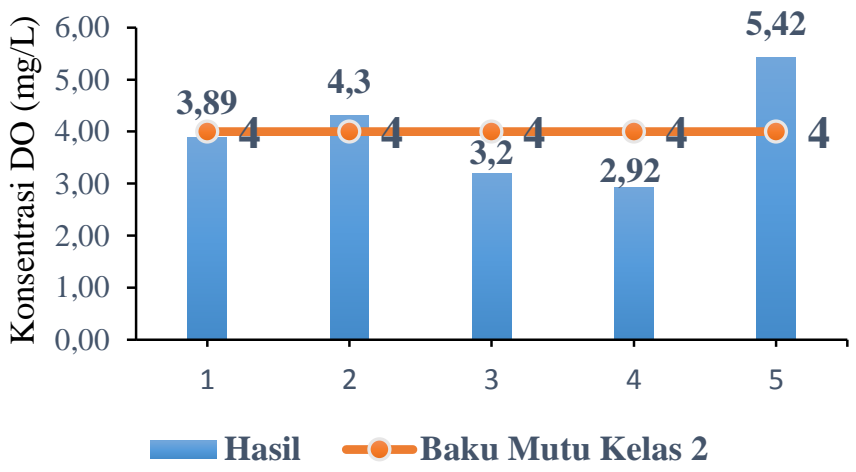

Gambar 4 Hasil Pengukuran Nilai DO di Lima Titik Sampel Danau Kandung Suli.

. Berdasarkan PP. 82 Tahun 2001 tentang Pengelolaan Kualitas Air dan Pengendalian Pencemaran Air, baku mutu II untuk parameter DO yaitu $4 \mathrm{mg} / \mathrm{L}$. Hasil penelitian menunjukkan nilai DO pada titik 3 dan 4 yaitu $3,2 \mathrm{mg} / \mathrm{L}$ dan 2,92 $\mathrm{mg} / \mathrm{L}$ terjadi penurunan. Rendahnya nilai DO disebabkan masuknya limbah rumah tangga dan aktivitas keramba ikan ke perairan yang memicu meningkatnya bahan organik di perairan sehingga mikroba memanfaatkan oksigen untuk melakukan proses dekomposisi bahan organik, proses dekomposisi memerlukan oksigen secara terus menerus, apabila bahan organik di perairan semakin meningkat maka oksigen yang dibutuhkan mikroba untuk mengoksidasi bahan organik semakin meningkat sehingga oksigen yang ada di perairan menjadi berkurang. Menurut Tobing dkk (2014) proses metabolisme pada ikan dapat mengkonsumsi oksigen hingga 2 kali lipat. Menurut Rizki dkk (2015) semakin tinggi nilai BOD dan COD maka semakin rendah nilai DO. Hal ini disebabkan mikroorganisme melakukan dekomposisi bahan organik (ditunjukkan dengan nilai BOD dan COD) yang memerlukan pasokan oksigen.

BOD

Hasil pengujian nilai BOD di Danau Kandung Suli disajikan pada Gambar 5.

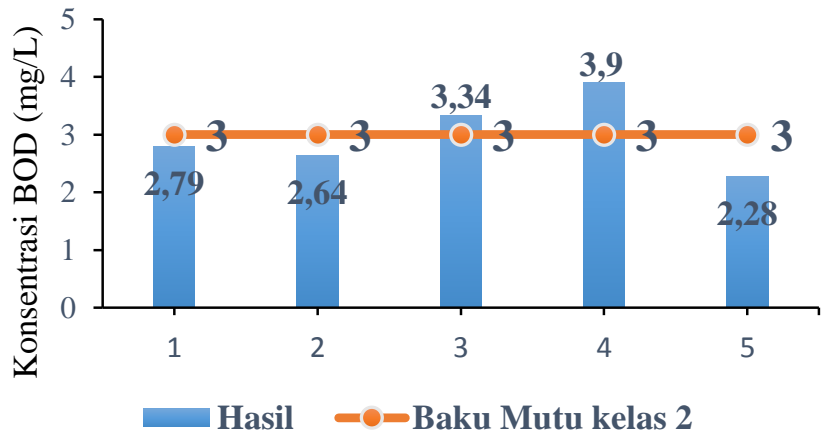

Gambar 5 Hasil Pengujian Nilai BOD di Lima Titik Sampel Danau Kandung Suli. 
Berdasarkan baku mutu kelas II Peraturan Pemerintah No. 82 Tahun 2001 tentang Pengelolaan Kualitas Air dan Pengendalian Pencemaran Air, nilai BOD pada titik 3 dan 4 yaitu $3,34 \mathrm{mg} / \mathrm{L}$ dan $3,9 \mathrm{mg} / \mathrm{L}$ telah melewati nilai ambang baku mutu air. Tingginya nilai BOD diduga adanya kegiatan budidaya ikan dan limbah domestik diperairan danau yang menyebabkan kandungan bahan organik menjadi tinggi. Merujuk pada pendapat Tatangindatu dkk (2011) tingginya BOD disebabkan jumlah oksigen yang dibutuhan mikroba untuk mengoksidasi bahan organik di perairan tinggi. Hasil pengamatan terdapat sisa pakan ikan yang tidak di bersihkan di perairan danau. Yuningsih dkk (2014) dan Tobing dkk (2014), menyebutkan bahwa sisa pakan dapat menyebabkan meningkatnya bahan organik diperairan meningkat, dikarenakan adanya penumpukkan bahan organik di perairan yang menyebabkan terjadinya proses dekomposisi oleh organisme pengurai yang semakin meningkat. Nilai BOD yang rendah terdapat pada titik 1, 2 dan 5 yang memenuhi baku mutu kelas II PP. 82 Tahun 2001 tentang Pengelolaan Kualitas Air dan Pengendalian Pencemaran Air. Rendahnya nilai BOD pada titik 1, 2 dan 5 dipengaruhi oleh penurunan nilai suhu, sehingga kadar BOD lebih rendah dari pada kadar BOD pada titik 3 dan 4. Selain itu rendahnya nilai BOD dikarenakan sedikitnya sumber pencemar pada titik tersebut.

COD

Hasil yang diperoleh dari pengujian COD disajikan pada Gambar 6.

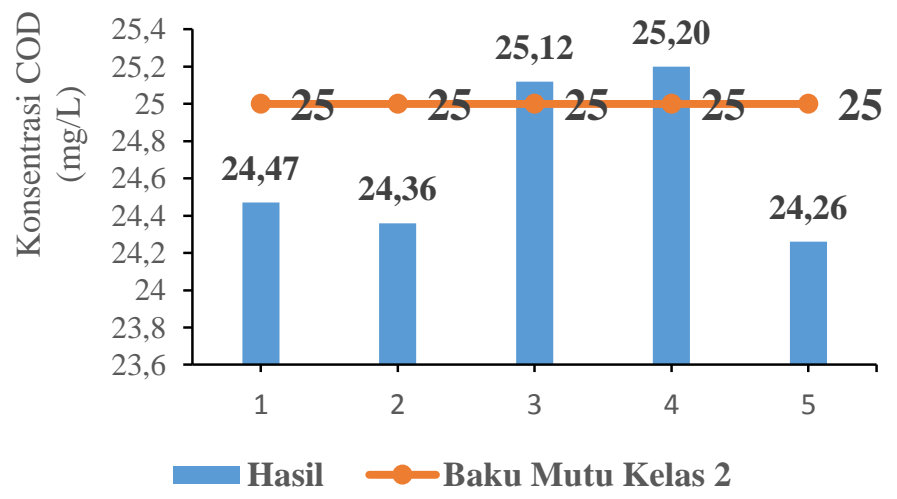

Gambar 6 Hasil Pengujian Nilai COD di Lima Titik Sampel Danau Kandung Suli.

Berdasarkan baku mutu kelas II PP. 82 Tahun 2001 tentang Pengelolaan Kualitas Air dan Pengendalian Pencemaran Air, Nilai COD yang diperoleh pada titik 3 dan 4 menunjukkan kenaikkan yaitu $25,12 \mathrm{mg} / \mathrm{L}$ dan $25,20 \mathrm{mg} / \mathrm{L}$. Tingginya nilai COD pada titik 3 dan 4 dipengaruhi oleh aktivitas masyarakat yang menghasilkan limbah domestik dan kegiatan budidaya ikan sebagai sumber utama pencemaran. Menurut Pujiastuti dkk (2013) menyatakan bahwa sisa metabolisme pada ikan dan pemberian pakan ikan menggunakan pellet dapat meningkatkan nilai COD yang disebabkan dari penumpukan bahan organik di perairan. Selain itu, menurut Zaharudin dkk (2016) meningkatnya nilai COD di perairan danau disebabkan masuknya limbah domestik yang mana bahan organik yang terdapat di perairan sukar didegradasi secara biologis. Titik 1 nilai COD terjadi penurunan sebesar $24,47 \mathrm{mg} / \mathrm{L}$, titik 2 sebesar 24,36 mg/L dan titik 5 sebesar 24,26 mg/L sesuai baku mutu kelas II PP. 82 Tahun 2001 tentang Pengelolaan Kualitas Air dan Pengendalian Pencemaran Air. Rendahnya nilai COD dipengaruhi jauhnya jarak titik pengambilan sampel dengan sumber utama pencemaran dan sedikitnya sumber pencemar pada titik pengambilan sampel. 


\section{TSS}

Hasil pengujian TSS yang diperoleh disajikan pada Gambar 7.

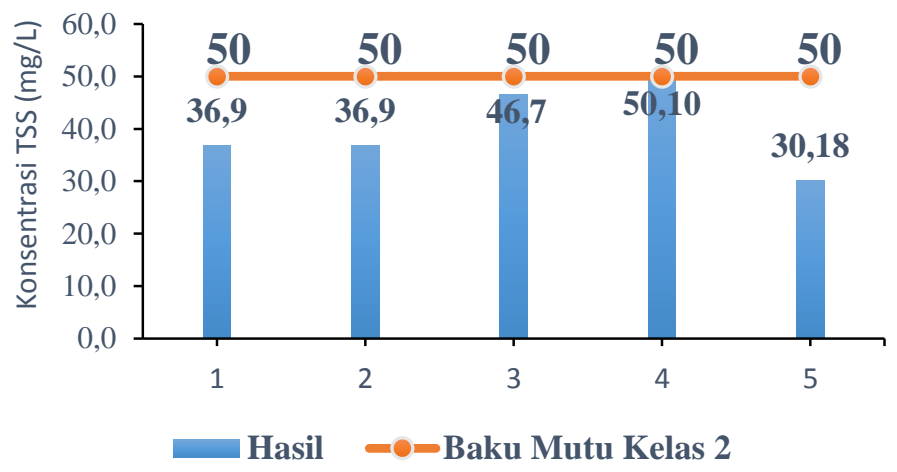

Gambar 7 Hasil Pengujian Nilai TSS di Lima Titik Sampel Danau Kandung Suli.

Berdasarkan baku mutu kelas II Peraturan Pemerintah No. 82 Tahun 2001 tentang Pengelolaan Kualitas Air dan Pengendalian Pencemaran Air, kadar TSS pada titik 4 telah melebihi ambang baku mutu. Ini disebabkan lokasi titik 4 terdapat aktivitas rumah tangga seperti mandi dan mencuci serta aktivitas budidaya ikan. Berdasarkan hasil pengamatan, disekitar lokasi titik 4 ditemukan sisa pakan yang tidak termakan oleh ikan. Rizki dkk (2015), Putra dkk (2014), Tobing dkk (2014) menyatakan bahwa tingginya nilai TSS dapat disebabkan oleh naiknya bahan organik yang bersumber dari limbah domestik, metabolisme ikan dan sisa pakan yang akan terakumulasi di perairan, pakan yang diberikan kepada ikan hanya $70 \%$ yang akan dikonsumsi oleh ikan, sedangkan 30\% akan tertinggal dan terbuang.

\section{TDS}

Hasil pengukuran TDS disajikan pada Gambar 8.

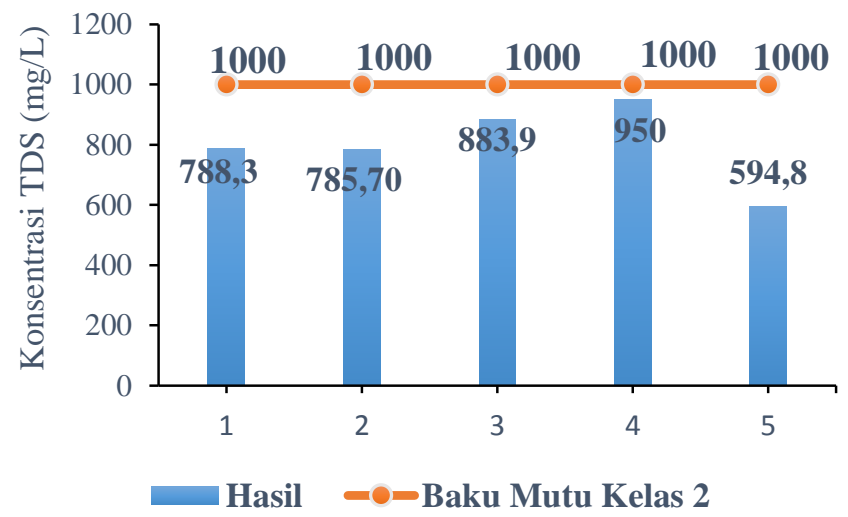

Gambar 8 Hasil Pengukuran Nilai TDS di Lima Titik Sampel Danau Kandung Suli.

Berdasarkan baku mutu kelas I, II dan III PP. 82 Tahun 2001 tentang Pengelolaan Kualitas Air dan Pengendalian Pencemaran Air, kadar TDS pada setiap titik masih berada pada ambang batas baku mutu. Tingginya nilai TDS pada titik 4 dan 3 disebabkan adanya aktivitas 
masyarakat seperti mandi, cuci, mengolah ikan dan pemberian pakan ikan yang menimbulkan sisa pakan di perairan, Jenis pakan (pellet) yang diberikan mengandung tinggi protein. Menurut Effendi (2003) meningkatnya bahan organik diperairan dapat dipengaruhi kandungan protein, detergen dan sabun yang menyebabkan kadar TDS di perairan meningkat.

\section{Fosfat $\left(\mathrm{PO}_{4}\right)$}

Hasil pengujian fosfat disajikan pada Gambar 9.

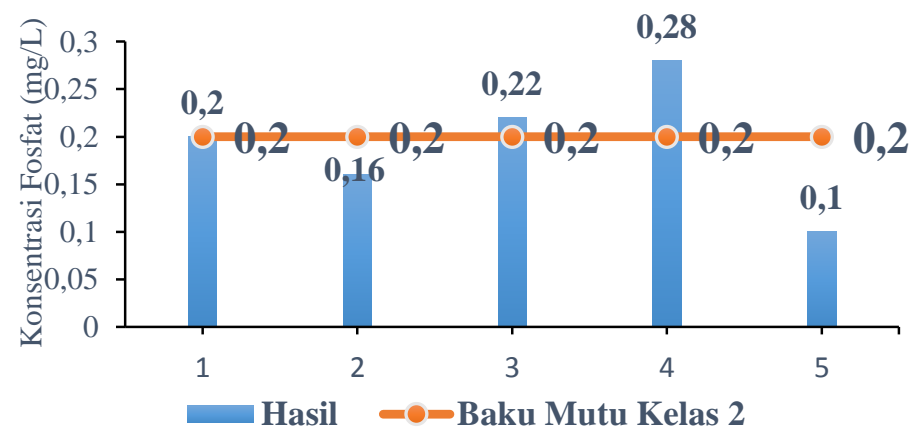

Gambar 9 Hasil Pengujian Nilai Fosfat di Lima Titik Sampel Danau Kandung Suli.

Berdasarkan baku mutu kelas I dan II PP. 82 Tahun 2001 tentang Pengelolaan Kualitas Air dan Pengendalian Pencemaran Air, nilai fosfat pada titik 3 dan 4 mengalami kenaikan. Tingginya nilai fosfat di perairan danau disebabkan oleh aktivitas budidaya ikan dan domestik. Menurut Effendi (2003) fosfat di perairan dapat berasal dari limbah domestik seperti detergen dan sabun. Selain itu, tingginya nilai fosfat berasal dari pakan ikan yang tidak semua termakan oleh ikan. Menurut Tobing dkk (2014) dan Handayani dkk (2010) menjelaskan bahwa kadar fosfat yang tinggi disuatu danau dapat dipengaruhi oleh limbah rumah tangga dan aktivitas budidaya ikan yang bersumber dari sisa pakan ikan dan sisa feses ikan.

\section{Nitrat (NO3)}

Hasil pengujian kadar nitrat disajikan pada Gambar 10.

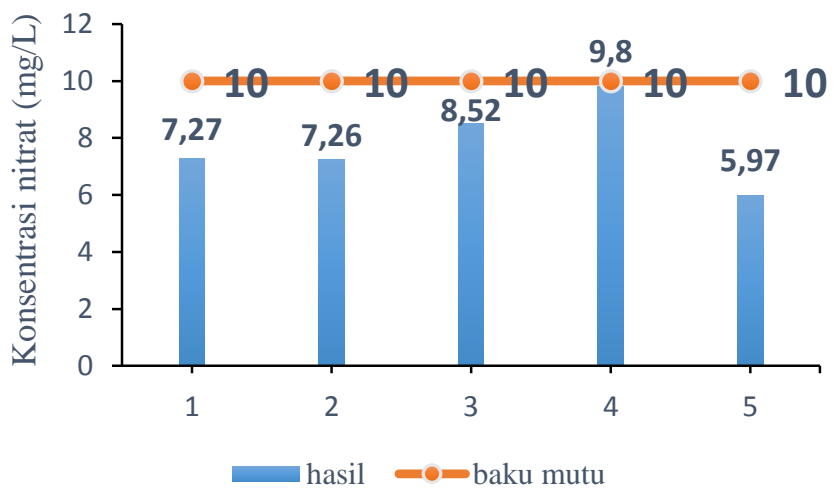

Gambar 10 Hasil Pengujian Nilai Nitrat di Lima Titik Sampel Danau Kandung Suli. 
Berdasarkan baku mutu kelas I dan II PP. 82 Tahun 2001 tentang Pengelolaan Kualitas Air dan Pengendalian Pencemaran Air, kadar nitrat pada setiap titik masih dibawah baku mutu. Namun nilai nitrat pada titik 4 mengalami kenaikkan yaitu $9,8 \mathrm{mg} / \mathrm{L}$. Naiknya nilai nitrat pada titik 4 disebabkan masuknya bahan organik ke perairan yang bersumber dari aktivitas budidaya ikan. Menurut Tobing dkk (2014) pemberian pakan ikan memicu peningkatan konsentrasi nitrat di perairan. Menurut Ginting (2011) yang dalam Tobing dkk (2014), kontribusi pakan ikan yang masuk keperairan memberikan pengayaan nitrat sebesar $86 \%$. Putra dkk (2014) menjelaskan bahwa buangan pakan ikan memiliki unsur hara utama berupa nitrogen, akibatnya terjadi pengayaan bahan organik di perairan. Effendi (2003) menjelaskan, kadar nitrat yang melebihi $5 \mathrm{mg} / \mathrm{L}$ menggambarkan terjadinya pencemaran antropogenik yang disebabkan oleh aktivitas manusia dan fases hewan. Sedangkan kadar nitrogen yang melebihi $0,2 \mathrm{mg} / \mathrm{L}$ menyebabkan terjadinya eutrofikasi perairan yang memicu pertumbuhan alga dan tumbuhan air secara cepat.

\section{KESIMPULAN}

1. Berdasarkan hasil analisis, terdapat beberapa parameter kualitas air yang melampaui baku mutu air kelas II PP Nomor 82 Tahun 2001 yakni sebesar 3,34 - 3,9 mg/L (BOD), $25,12-25,20 \mathrm{mg} / \mathrm{L}$ (COD), 50,10 mg/L (TSS) dan 0,22-0,28 mg/L (fosfat).

2. Sumber utama pencemaran air di Danau Kandung Suli berasal dari aktivistas domestik dan budidaya ikan.

\section{UCAPAN TERIMA KASIH}

Puji dan syukur kehadirat Allah SWT atas berkat dan rahmat-Nya sehingga saya dapat menyelasaikan tugas akhir saya. Terima kasih kepada dosen pembimbing saya Ibu Nurhayati dan Bapak Kiki Prio Utomo serta dosen penguji saya Bapak Arifin dan Ibu Jumiati. Terima kasih juga saya ucapkan kepada pihak Desa Kandung Suli, Kecamatan Jongkong, Kabupaten Kapuas Hulu serta keluarga dan rekan-rekan yang telah membantu dalam menyelesaikan tugas akhir saya. Semoga hasil penelitian ini dapat bermanfaat bagi semua pihak.

\section{DAFTAR PUSTAKA}

Effendi, H. 2003. Telaah Kualitas Air bagi Pengelolaan Sumber Daya dan Lingkungan Perairan. Kanisius. Yogyakarta.

Handayani, Cok,I,M.; Arthana, I,W.; Merit, I, N. 2010. Identifikasi Sumber Pencemar dan Tingkat Pencemaran Air di Danau Batur Kabupaten Bangli. Bali: Fakultas Pertanian. Universitas Udayana.

Peraturan Pemerintah No. 82 Tahun 2001 Tentang Pengelolaan Kualitas Air dan Pengendalian Pencemaran Perairan.

Pujiastuti, P.; Ismail, Bagus.; Pranoto. 2013. Kualitas dan Beban Pecemaran PerairanWaduk Gajah Mungkur. Surakarta: Prodi Analis Kimia. Fakultas Teknik. Universitas Setia Budi.

Putra, E.; Buchari, H.; Tugiyono. 2014. Pengaruh Kerapatan Kerampa Jaring Apung Terghadap Kualitas Perairan Waduk Way Terbabeng Kabupaten Lampung Utara. Lampung: Magister Ilmu Lingkungan. Universitas Lampung.

Rizki, A.; Yunasfi; Muhtadi, A. 2015. Analisis Kualitas Air dan Beban Pencemar di Danau Pondk Lapan Kecamatan Salapian Kabupaten Langket. Sumatra Utara: Program Studi Manajemen Sumberdaya Perairan. Fakultas Pertanian. Universitas Sumatra Utara. 
SNI 6989-57-2008. Tentang Metode Pengambilan Contoh Air Permukaan.

Syamiazi Noor, D.F.; Saifullah.; Indaryanto, R.F. 2015. Kualitas Air Di Waduk Nandra Kerenceng Kota Cilegon Provinsi Banten. Banten : Program Studi Perikanan. Universitas Sultan Agung Tirtayasa.

Tatangindatu, F.; Kalesaran, O.; Rompas, R. 2011. Studi Parameter Fisika Kimia Air pada Areal Budidaya Ikan di Danau Tondano Desa Paleloan. Minahasa: Budidaya Perairan. Sulawesi Utara.

Tobing, Sudoyo L.; Barus, Ternala A.; Desrita. 2014. Analisis Kualitas Air Akibat Keramba Jaring Apung di Danau Toba Dusun Sualan Desa Sibaganding Kabupaten Simalungun Sumatra Utara. Sumatra Utara: Program Studi Manajemen Sumberdaya Perairan. Fakultas Pertanian. Universitas Sumatra Utara.

Yuningsih, H, D.; Soedarsono, P.; Anggoro, S. 2014. Hubungan Bahan Organik dengan Produktivitas Perairan pada Kawasan Tutupan Eceng Gondok Perairan Terbuka dan Keramba Jaring Apung di Rawa Pening. Semarang: Program Studi Manajemen Sumberdaya Perairan. Jurusan Perikanan. Fakultas Perikanan dan Ilmu Kelautan. Universitas Diponegoro. Jawa Tengah.

Zaharuddin, N.; Wahyuningsih, H.; Muhtadi, A. 2016. Penentuan Kualitas Air di Danau Kelapa Gading Kelurahan Kisaran Naga Kabupaten Asahan. Medan: Program Studi Manajemen Sumberdaya Perairan. Fakultas Pertanian. Universitas Sumatra Utara. 